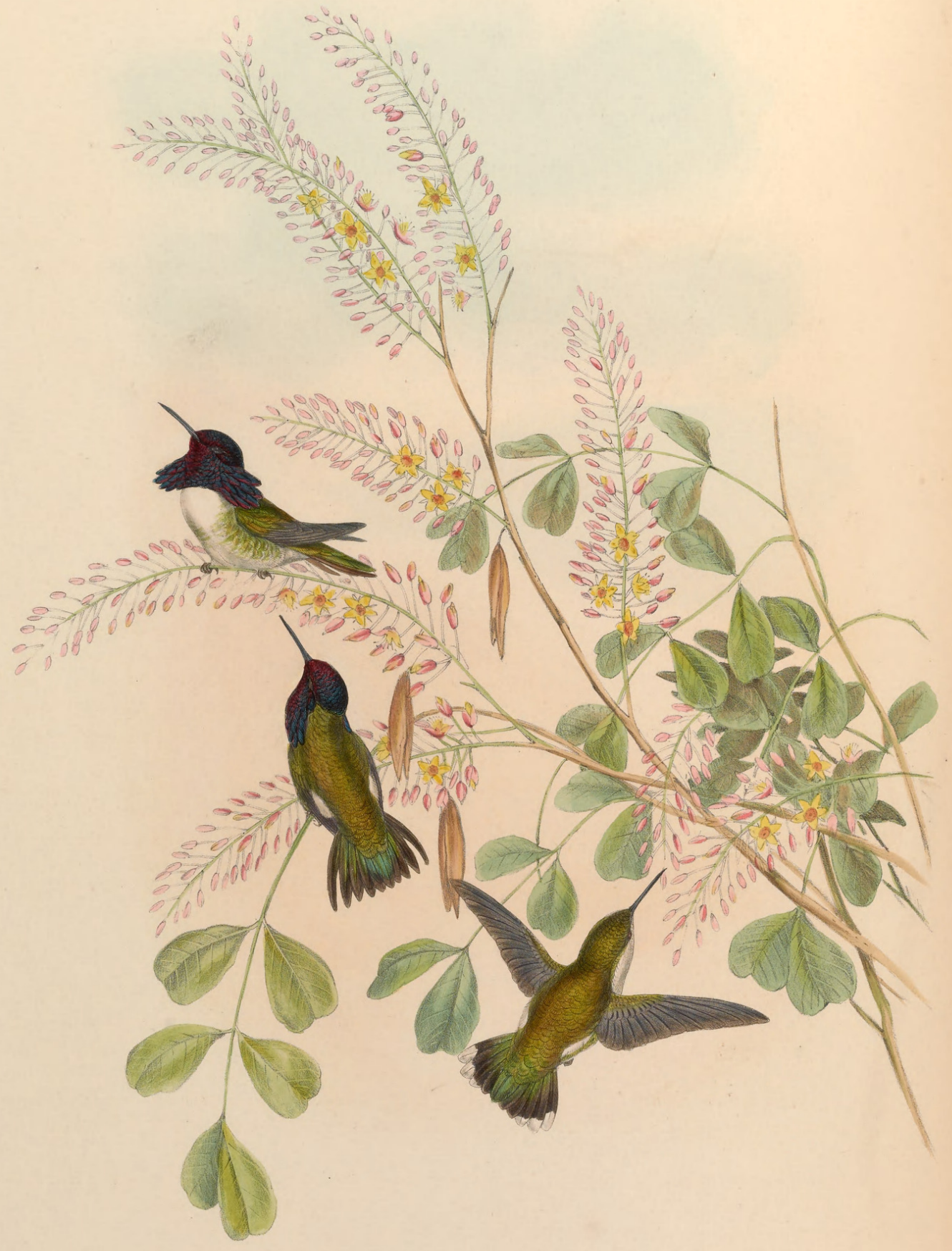




\section{CALYPTE COSTA.}

\section{Costa's Calypte.}

Ornismya Coste, Bourc. Rev. Zool. 1839, p. 294.-Ib. Ann. de la Soc. Sci. de Lyon, 1840, p. 225. pl. 2.-Voy. de la Vénus, pl. 2.-Longuem. et Parz. Rev. Zool. 1840, p. 71 .

Mellisuga Costa, Gray and Mitch. Gen. of Birds, vol. i. p. 113, Mellisuga, sp. 83.

Selasphorus Coste, Bonap. Consp. Gen. Av., p. 82, Selasphorus, sp. 4.-Ib. Rev. et Mag. de Zool. 1854, p. 257.

Atthis Costae, Reichenb. Aufz. der Colibris, p. 12.

Trochilus Costae, Reichenb. Troch. enumer., p. 10.

Here we have a very beautiful little bird, conspicuous not only for the rich brilliancy of its head and throat, but for the colouring of those parts being of an unusual hue-a glittering metallic-lilac, neither easy to describe nor to depict, and which can only be feebly represented even with the aid of silver and the finest copal colours; indeed, to acquire anything like a correct notion of its beauty, the bird itself must be seen, neither description nor figure giving an adequate idea of its splendour. I am indebted for numerous specimens of this lovely bird to the late M. Floresi, who collected them in the valleys of the Sierra Madre in Mexico. From thence, throughout the western part of Mexico, and in some parts of California, the bird is probably found.

The first description of this bird appeared in the "Revue Zoologique" for 1839, from the pen of M. Bourcier, who gave it the specific appellation of Coste, in honour of the Marquis de Costa of Chambéry, the possessor of a very beautiful collection of birds. In the form of its tail, and in the extent of the metallic colouring of its head and throat, it bears a striking resemblance to the $C$. Annee, but is at once distinguished from that species by its smaller size, as well as by the different hue of the head and neck. Of its habits and economy nothing has yet been recorded.

The sexes present nearly the same differences that are observable in those of $C$. Annce.

The male has the head, ear-coverts, throat, and the elongated ruff-like feathers on the sides of the neck, brilliant deep metallic-lilac; all the upper surface and wing-coverts golden green ; wings purple-brown ; six central tail-feathers bronzy green; two outer tail-feathers brownish grey with darker tips; under surface dull white, washed with bronzy green on the flanks; bill and feet blackish brown.

At a younger age the head is of the same hue as the body; a few of the fine feathers of the throat have appeared; the abdomen is bronzy green; the apical half of the outer tail-feathers are black, and their tips white.

In the female the whole of the upper surface is dull golden green; under surface dull greyish white, with a few dots of brown on the throat; wings purplish brown; central tail-feathers bronzy green; lateral feathers grey at the base, succeeded by deep black, and tipped with white.

The figures are the size of life. The plant is the Logwood (Lignum Campechianum). 


\section{$2 \mathrm{BHL}$ Biodiversity Heritage Library}

Gould, John. 1855. "Calypte costæ, Costa's Calypte. [PI. 134]." A monograph of the Trochilidae, or family of humming-birds 3, https://doi.org/10.5962/p.316943.

View This Item Online: https://www.biodiversitylibrary.org/item/109468

DOI: https://doi.org/10.5962/p.316943

Permalink: https://www.biodiversitylibrary.org/partpdf/316943

\section{Holding Institution}

Smithsonian Libraries

\section{Sponsored by}

Smithsonian Institution Libraries

\section{Copyright \& Reuse}

Copyright Status: NOT_IN_COPYRIGHT

This document was created from content at the Biodiversity Heritage Library, the world's largest open access digital library for biodiversity literature and archives. Visit BHL at https://www.biodiversitylibrary.org. 